\title{
КУЛЬТУРНАЯ ДИПЛОМАТИЯ КНР В ОТНОШЕНИИ АСЕАН (2003-2021 Гг.)
}

\author{
ШИ ДАНЬДАНЬ \\ Белорусский государственный университет, \\ Минск, Республика Беларусь
}

\begin{abstract}
Аннотация. В статье рассматриваются основные направления культурной дипломатии КНР в отношении Ассоциации государств Юго-Восточной Азии (АСЕАН) в 2003-2021 гг. АСЕАН является не только политической и экономической, но и культурной межправительственной организацией, состоящей из 10 государств, из которых три - соседи Китая (Лаос, Мьянма и Вьетнам). В ходе комплексного анализа проблемы выделено три основных направления культурной дипломатии Китая в отношении АCEАН: продвижение китайской культуры; популяризация китайского языка; расширение образовательных обменов. Охарактеризована договорно-правовая база культурного взаимодействия, выявлены основные механизмы и инструменты ее реализации.

Предпринято первое в белорусской историографии комплексное исследование культурной дипломатии КНР в отношении АСЕАН. Автор доказал, что распространение китайской культуры в рамках АСЕАН:

1) осуществляется преимущественно через создание китайских культурных центров и проведение регулярных культурных мероприятий, включающих культурные форумы, фестивали искусства и кино;

2) главным инструментом популяризации китайского языка в странахчленах АСЕАН являются классы и институты Конфуция;

3) активное развитие образовательных контактов с участниками Ассоциации привлекает все большее число студентов из этого региона в Китай, к 2021 г. их численность достигла почти 100 тыс.

Результаты данной работы могут быть использованы для комплексных исследований внешней политики и дипломатии КНР.
\end{abstract}

Ключевые слова: КНР; АСЕАН; внешняя культурная политика; культурная дипломатия; многосторонние культурные связи; культурная стратегия; стратегическое партнерство; Сообщество единой судьбы человечества.

Образец цитирования: Ши Даньдань. Культурная дипломатия КНР в отношении АСЕАН (2003-2021 гг.) // Актуальные проблемы международных отношений и глобального развития: сб. науч. ст. Минск, 2021. Вып. 9. С. 162-180. https://doi.org/10.33581/2311-9470-2021-9-162-180

Введение. Географическое положение и бурное развитие государств - членов АСЕАН определяют важность этой межправительственной организации в стратегии культурной дипломатии Китая. 
Участники АСЕАН являются региональными (Индонезия, Малайзия, Сингапур, Таиланд, Филиппины, Камбоджа и Бруней) или непосредственными (Вьетнам, Лаос и Мьянма) соседями Китая, и без изучения культурных связей с ними невозможно эффективно продвигать политику добрососедства и создания благоприятной обстановки для мирного развития Китая и модернизации страны.

Культурное сотрудничество между Китаем и АСЕАН осуществлялось в благоприятных политических условиях. В июле 1991 г. прежний министр иностранных дел КНР Цянь Цичен принял участие в 24-й сессии конференции министров иностранных дел государствчленов АСЕАН в Малайзии, положившей начало двустороннему диалогу ${ }^{1} .16$ декабря 1997 г. председатель Китая в тот период Цзян Цзэминь и лидеры стран АСЕАН в Малайзии провели первую неформальную встречу и выпустили «Совместное заявление», в котором объявили, что готовы установить партнерские отношения добрососедства и взаимного доверия, ориентированные на XXI век ${ }^{2}$. В октябре 2003 г. на 7-м саммите Китай - АСЕАН председатель Госсовета Китая Вэнь Цзябао договорился с руководством Ассоциации об установлении отношений стратегического партнерства. По оценке Вэнь Цзябао, это открыло новый этап сотрудничества ${ }^{3}$.

Со времени начала диалога взаимодействие в области политики, экономики и безопасности обеих сторон получило заметное развитие, однако в условиях экономического рывка Китая и реализации инициативы «Один пояс, одни путь» (с 2014 г.) в странах АСЕАН возросли сомнения и недоверие к проводимой Пекином политике. С целью преодоления таких настроений в декабре 2005 г. премьер Госсовета КНР Вэнь Цзябао предложил определить культуру как одно из пяти новых приоритетных направлений сотрудничества между Китаем и Ассоциацией ${ }^{4}$. Многостороннее и двустороннее взаимодействие в рамках АCЕАН+КНР и АСЕАН+3 (КНР, Япония и Южная Корея) распространяется и на культуру.

\footnotetext{
${ }^{1}$ Ходоза С. С. История развития взаимоотношений Китая в АСЕАН // Вестник Томского государственного университета. 2020. № 388. С. 150.

${ }^{2}$ Справка: история развития отношений между КНР и АСЕАН // Интернет-версия Жэньминь жибао. [Электронный ресурс]. 2010. URL: http://russian.people.com.cn/95181/7181801.html (дата обращения: 05.09.2021).

${ }^{3}$ Сюй Цзякан, Гу Сяосун. Чжунго дунмэн няньцзянь 2004 (Ежегодник Китай-АСЕАН 2004 г.) Пекин : Сяньчжуан шуцзюй, 2004. С. 86.

${ }^{4}$ Сюй Цзякан, Гу Сяосун. Чжунго дунмэн няньцзянь 2006 (Ежегодник Китай-АСЕАН 2006 г.) Пекин: Сяньчжуан шуцзюй, 2006. С. 156.
} 
Методология исследования. Объектом исследования выступает внешняя культурная политика КНР в XXI в. Предметом - культурная дипломатия КНР в отношении АСЕАН в 2003-2021 гг. Хронологические рамки исследования охватывают период с установления отношений стратегического партнерства между КНР и АСЕАН (2003 г.) до 2021 г., когда культурный форум Китай - АСЕАН был включен в Список важных платформ для культурных обменов и связей между народами в рамках инициативы «Один пояс, один путь».

Целью исследования является характеристика культурной политики и дипломатии КНР в отношении АСЕАН на протяжении 20032021 гг. Для этого поставлены следующие задачи: определить интересы Китая в АСЕАН, раскрыть содержание и специфику культурного взаимодействия Китая со странами АСЕАН, проследить эволюцию договорно-нормативной базы, выявить механизмы ее реализации.

Автор использовала общенаучные (анализ, синтез, индукция, дедукция) и специальные методы (нарративный, историкоретроспективный, историко-сравнительный, историко-системный, институциональный, структурно-функциональный, анализа документов, включенного наблюдения), а также системный, междисциплинарный и ценностный подходы.

Обзор источников и литературы по теме. Важными источниками исследования послужили официальные документы АСЕАН и КНР: Совместные заявления КНР и АСЕАН; Меморандум о взаимопонимании между АСЕАН и КНР в области культурного сотрудничества от 3 августа 2005 г.; пятилетние Планы действий по реализации Совместной декларации о стратегическом партнерстве Китая и ACEAH, начиная с 2005 г.; пятилетние планы развития китайской культуры; План Министерства культуры КНР по развитию культурного сотрудничества в рамках инициативы «Один пояс, один путь» (20162020 гг.). Ценный материал по исследуемой проблеме содержится в информационных ежегодниках «Китай - АСЕАН». Автор использовала также публикации СМИ (агентство «Синьхуа», газета «Жэньминь жибао») и материалы о культурном сотрудничестве, размещенные на официальных сайтах АСЕАН и МИД Китая.

При подготовке статьи изучались публикации следующих китайских исследователей: Ли Фуцзян (профессор Гуансийского университета национальностей, 2006) [1], Цзян Юлянь (профессор Наньнинского профессионально-технического университета, 2006) [2], Хуан Цзюнь (профессор политико-юридического факультета Гуан- 
сийского университета национальностей, 2009) [3], Чжан Чэнся (декан факультета международного образования университета Гуйчжоу, 2012) [4], Ли Хун (профессор института бизнеса при Гуансийском университете, 2012) [5], Хуан Яодун (исследователь Центра КНРАСЕАН при Гуансийском университете национальностей, 2014) [6], Ян Хуа (профессор Гуансийского университета искусств, 2014) [7], Чжао И (профессор Пекинского университета международных исследований, 2014 г.) [8], Ян Баоцзюнь (профессор факультета международных отношений Пекинского университета, 2015) [9], Чжоу Шисинь (научный сотрудник Шанхайского института международных исследований, 2016) [10], Тан Сяосун (профессор Центра совместных инноваций Морского Шелкового пути, 2017) [11], Сюй Бу (посол КНР в АСЕАН, 2018) [12], Ли Чинлинь (профессор факультета журналистики и коммуникации Гуансийского университета, 2018) [13], Лян Жучцян (профессор Гуансийского финансовоэкономического института, 2019) [14], Чжан Сипин (директор международного Центра китаеведения, 2019) [15], Юй Хунзюнь (заместитель начальника отдела международных связей при ЦК КПК, 2020) [16], Син Лицзюй (научный сотрудник Центра международных культурно-гуманитарных обменов, 2021) [17].

Особый интерес представляют исследования Цзян Юлиан, Ли Хун, Чжоу Шисинь и Сюй Бу. Работа Цзян Юлянь [2, с. 21] посвящена анализу исторических, внешнеполитических и культурных факторов, влияющих на связи КНР с регионом. В публикации Ли Хуна [5, с. 18] выявляется взаимосвязь культурной и экономической дипломатии Китая по отношению к АСЕАН.

Исследование Чжоу Шисинь [10, с. 85] раскрывает возможности и выгоды сотрудничества Китая с Ассоциацией. Посол КНР в АСЕАН (2015-2017 гг.) Сюй Бу рассматривал взаимодействие Китая и АСЕАН в области культуры как важный аспект деятельности. Он отметил «огромные успехи в институализации культурного сотрудничества» и то обстоятельство, что «культурно-гуманитарное сотрудничество стало новым столпом стратегического партнерства КНР и ACEAH» [12, c. 11].

Русскоязычная историография, где рассматривался бы вопрос культурного сотрудничества между КНР и АСЕАН, малочисленна. Среди авторов - Р. А. Полончук [18], Р. И. Файншмидт [19] и Чжай Кун [20]. Р. А. Полончук определил культурное и образовательное сотрудничество Китая со странами Юго-Восточной Азии как «мяг- 
кую силу». Р. И. Файншмидт исследовал китайский вектор в современной политике АСЕАН и указал факторы, влияющие на политику Ассоциации в отношении Пекина, среди которых и культура.

Результаты исследования. В качестве начального этапа взаимодействия автор выделяет 2003-2012 гг. Культурное сотрудничество между КНР и АСЕАН реализовывалось на основе соответствующей договорно-правовой базы. Основными политическими документами стали совместная Декларация АСЕАН+КНР (8 октября, 2003 г.) $)^{5}$ и План по осуществлению Совместной декларации о стратегическом партнерстве Китая и АСЕАН (2005-2010 гг.) 6 . В Декларации сформулирована цель взаимодействия в области культуры - «укрепление взаимопонимания и дружбы между народами». В рамках Плана были выделены приоритетные направления взаимодействия в области культуры: культурная индустрия, артистические и художественные обмены, подготовка кадров.

3 августа 2005 г. на заседании министров культуры $\mathrm{ACEAH+3}$ (КНР, Япония и Южная Корея) министром культуры Китая Сун Цзячжэном был подписан «Меморандум о взаимопонимании между Китаем и АСЕАН в области культурного сотрудничества» ${ }^{7}$. По оценке Сун Цзячжэна, меморандум стал первым документом о культурном сотрудничестве, подписанным Китаем с региональной организацией, что добавило новое направление в договорно-правовую базу сотрудничества между сторонами; культурные обмены стали осуществляться на его основе ${ }^{8}$.

\footnotetext{
${ }^{5}$ Вэй Цзябао цзунли цзай ди ци цы чжунго юй дунмэн лидаожэнь жуэйи шан дэ цзянхуа [Вы ступление премьера Госсовета Вэнь Цзябао на седьмой встрече лидеров Китая и АCЕАН] // Министерство иностранных дел Китайской Народной Республики. [Электронный ресурс]. 20 03. URL: https://www.fmprc.gov.cn/web/gjhdq_676201/gjhdqzz_681964/lhg_682518/zyjh_682528 /t575580.shtml (дата обращения: 05.09.2021).

${ }^{6}$ Plan of Action to Implement the Joint Declaration on ASEAN-China Strategic Partnership for Pea ce and Prosperity (2011-2015) // Посольство КНР в Малайзии. [Электронный ресурс]. 2010. UR L: http://my.china-embassy.org/eng/zt/eastasia/zywj/t772063.htm (дата обращения: 05.09.2021).

${ }^{7}$ Chairperson's Press Statement of the Second Meeting of the ASEAN Ministers Responsible for C ulture and Arts (AMCA) and the AMCA Plus Three Bangkok // ACEAH+3. [Electronic resource]. 2005. URL: https://aseanplusthree.asean.org/chairpersons-press-statement-of-the-second-meeting-o f-the-asean-ministers-responsible-for-culture-and-arts-amca-and-the-amca-plus-three-bangkok/. (да та обращения: 05.09.2021).

8 Дунмэн вэньхуа бучжан хуэйи цзай маньгу цзюйсин чжунго юй дунмэн цяньшу вэньхуа хэч зо вэйванлу (Заседание министров культуры АСЕАН+3 состоялось в Бангкоке и стороны под писали меморандум о взаимопонимании между Китаем и АСЕАН в области культурного сот рудничества) // МИД КНР. [Электронный ресурс]. 2005. URL: https://www.fmprc.gov.cn/web/g jhdq_676201/gjhdqzz_681964/lhg_682542/zwbd_682562/t440450.shtml (дата обращения: 05.09.2 021).
} 
Главными платформами сотрудничества в области культурой индустрии являются Культурный форум Китай - АСЕАН и ЕХРО Китай - АCЕАН. 18 сентября 2006 г. в г. Наньнин (Гуанси-Чжуанский автономный район) состоялось открытие первого культурного форума Китай - АСЕАН. Ван Юнчжан, директор департамента культурной индустрии Министерства культуры КҮН, заявил, что цель Форума - поиск Китаем каналов сотрудничества со странами АСЕАН в развитии культурных индустрий в форматах «ACEAH+3» и «ACE$\mathrm{AH}+$ Китай». Город Наньнин одновременно является местом проведения ЕХРО Китай - АСЕАН; обе эти платформы содействуют продвижению сотрудничества в области культурной индустрии.

Ван Юнчжан констатировал, что культурные индустрии китайских провинций Гуанси и Юньнань, а также региона дельты реки Чжуцзян наладили сотрудничество со странами АCEАН по таким направлениям, как исполнительское и прикладное искусство, выставки, кино и телевидение, публикации, и подчеркнул необходимость обратить внимание на новые области культурной индустрии (анимация и онлайн игры $)^{9}$.

Гуанси-Чжуанский автономный район КНР в связи со своим географическим положением стал ключом для раскрытия потенциала совместной культурной индустрии с АСЕАН. Юй Ичжун, глава департамента культуры этого района, на Культурном форуме Китай АСЕАН (ноябрь 2008 г.) отметил, что возглавляемый им департамент счел целесообразным разработать «План развития культурной индустрии экономической зоны Гуанси-Бейбу».

По оценке Ли Цзяньпина, директора Института литературы и истории Академии общественных наук Гуанси, в стратегии развития Китая район позиционируется как платформа взаимодействия в области культурной индустрии со странами - участницами АCEAH ${ }^{10}$.

Первым проектом культурной индустрии в рамках культурного форума Китай - АСЕАН является Соглашение об инвестициях и строительстве театра для традиционных постановок и коммерческих

\footnotetext{
${ }^{9}$ Чэн Баоцзян. Шоцзе чжунго дунмэн вэньхуа лунтань цзай наньнин цзюйсин (Первый культ урный форум КНР и АСЕАН состоялся в городе Наньнине) // Газета Юньнань. 2006. 19 сентя бря. С. 10.

${ }^{10}$ Цинь Вэнь. чжунго дунмэн вэньхуа лунтань дай бяо фаянь цзуншу (Обзор выступлений пр едставителей участников Культурного форума КНР и АСЕАН) // Газета Гуанси. 2008. 4 нояб ря. С. 11.
} 
представлений в районе залива Халонг провинции Куангнинь (Вьетнам), подписанное в сентябре 2006 г. ${ }^{11}$

В ноябре 2010 г. в Гуанси открылся учебно-подготовительный культурный центр КНР и АСЕАН ${ }^{12}$, а годом спустя Гуанси и Ассоциация подписали «План действий по культурному сотрудничеству». При национальном музее Гуанси в конце 2011 г. началась работа Союза музеев АCEAH $+1^{13}$.

Известными брендами культурного сотрудничества в автономном районе стали Международный фестиваль народной песни в Наньпине, гастрольная деятельность «Лю Саньцзе» (основная тематика этого коллектива связана с культурой, историей национальных меньшинств Китая), культурный форум АСЕАН и КНР. Фестиваль народной песни в г. Наньпине совпадает с ежегодной выставкой ЕХРО КНР - АСЕАН и спонсируется Министерством культуры, Национальным этническим комитетом и правительством Наньнина. Цель фестиваля - сохранение и популяризация искусства разных национальностей.

Параллельно с этим мероприятием проходят выставки мод, фестивали этнических меньшинств и кулинарные классы. Первый Фестиваль народной песни в рамках ЕХРО КНР - АСЕАН (ноябрь 2004 г.) привлек более 50 тыс. зрителей ${ }^{14}$.

Кроме многосторонних платформ в рамках АCЕАН, район Гуанси развивает двусторонние культурные обмены с отдельными членами Ассоциации в рамках программы Министерства культуры. Так, в январе 2012 г. Гуанси участвовал в программе «Веселый китайский Новый год», отправив делегацию в составе 150 человек в Сингапур.

\footnotetext{
${ }^{11}$ Цзяолю хоудун ши гуанси вэньхуа цай дунмэн гоцзя идэ юэ лай юэ до чжиинь [Культура завоевывает все больше и больше друзей в странах АСЕАН] // Правительство КНР. [Электронный ресурс]. 2007. URL: https://china.gov.cn.admin.kyber.vip/jrzg/2007-10/28/content_788 373.htm

12 Чжунго дунмэн вэньхуа пэйсюнь чжунсинь цзай гуанси цзему (учебно-подготовительный центр в области культуры между КНР и АСЕАН) // Пресс-канцелярии Госсовета КНР. [Элект ронный ресурс]. 2010. URL:http://www.scio.gov.cn/hzjl/hdjj/wz/Document/795515/795515.htm. ( дата обращения: 05.09.2021).

132012 Чжунго дунмэн хэцзо (Сотрудничество между Китаем и АСЕАН в 2012 г.) // МИД КН P. [Электронный ресурс]. 2012. URL: https://www.fmprc.gov.cn/web/gjhdq_676201/gjhdqzz_681 964/lhg 682518/zywj_682530/t990371.shtml (дата обращения: 05.09.2021).

${ }^{14}$ Сун Цзячэн. Чжунго вэньхуа наньцзянь 2005 (Ежегодник по развитию культуры Китая 2005 г.). Пекин: Синьхуа , 2006. 938 с.
} 
Ее участники познакомили жителей этой страны с нематериальным культурным наследием национальности чжуаны ${ }^{15}$.

С целью популяризации китайской культуры и языка за границей правительство Китая оказывают финансовую и техническую поддержку институтам Конфуция ${ }^{16}$. В апреле 2007 г. член Постоянного комитета Политбюро ЦК КПК Ли Чжанчунь отметил, что это направление являются важной частью стратегии внешней пропаганды Китая, направленной на построение гармоничного мира ${ }^{17}$.

1 января 2010 г. была официально создана Зона свободной торговли Китай - ACЕАН, что обусловило рост спроса на изучение китайского языка ${ }^{18}$. Отметим, что первый Институт Конфуция в странах Ассоциации был открыт 3 августа 2006 г. в Таиланде ${ }^{19}$. По состоянию на конец 2012 г. в регионе функционировало 26 институтов Конфуция и 19 классов Конфуция, но размещение было неравномерным: если в Таиланде их насчитывалось 23, то в Индонезии - 6. Институты Конфуция в странах АСЕАН играют важную роль в ознакомлении населения с лучшими достижениями китайской культуры и являются важным элементом внешней пропагандистской работы Китая $[18$, c. 20$]$.

В октябре 2010 г. премьер Госсовета КНР Вэн Цзябао на заседании АСЕАН+КНР предложил План увеличения численности студентов по обмену между КНР и АСЕАН ${ }^{20}$. Для его реализации в Китае были созданы такие платформы содействия образовательным обме-

\footnotetext{
${ }^{15}$ Цай Ву. Чжунго вэньхуа наньцзянь 2013 (Ежегодник по культуре КНР 2013 г.). Пекин: Синьхуа, 2014. 790 с.

${ }^{16}$ Кокарев К. А., Комиссина И. Н., Сведенцов В. Л. Политика «мягкой силы» Китая в Азии // Проблемы национальной стратегии. 2019. № 3. С. 11-67.

${ }^{17}$ Цзохао ханьюй туйгуан гунцзо цзэнцзиньтун шице ляоце хэ юйи (Укрепление дружбы между Китаем и миром посредством популяризации китайского языка на международной арене) // Правительство КНР. [Электронный ресурс]. 2007. URL: http://www.gov.cn/ldhd/200704/24/content_594800.htm (дата обращения: 05.09.2021).

18 Чжунго дунмэн цзымао цюй (Зона свободной торговли КНР и АСЕАН) // Правительство КНР. [Электронный ресурс]. 2011. URL: http://www.gov.cn/wszb/zhibo469/content_1913373. htm (дата обращения: 05.09.2021).

${ }^{19}$ Кунцзин дасюэ кунцзы сюэюань (Институт Конфуция при Университете Кхон Каен) // Портал Института Конфуция при Университете Кхон Каен. [Электронный ресурс]. 2006. URL: https://confucius.kku.ac.th/home/ch/index.php/home/about (дата обращения: 05.09.2021).

${ }^{20}$ Вэй Цзябао цзунли цзай ди ши сань цы чжунго юй дунмэн лидаожэнь жуэйи шан дэ цзянхуа (Выступление премьера Госсовета Вэнь Цзябао на тринадцатой встрече лидеров Китая и ACEAН) // Министерство иностранных дел Китайской Народной Республики. [Электронный pecypc]. 2010. URL: https://www.fmprc.gov.cn/web/gjhdq_676201/gjhdqzz_681964/dmldrhy_683 911/zyjhywj_683921/t765330.shtml (дата обращения: 05.09.2021).
} 
нам, как Неделя образовательных обменов между Китаем и регионом, Круглый стол министров образования КНР и АСЕАН [7, с. 44]. По данным МИД, начиная с 2005 г. правительство Китая ежегодно увеличивало число правительственных стипендий, предоставляемых гражданам стран - участниц АСЕАН. В 2010 г. оно достигло 3 337, что на 329\% выше, чем в 2005 г. К концу 2011 г. в Китае обучалось около 50 тыс. студентов из стран АСЕАН, а число китайских студентов, обучающихся в университетах Ассоциации, достигло 70 тысяч ${ }^{21}$.

Согласно Меморандуму о взаимопонимании между правительством КНР и правительствами стран - членов АСЕАН о создании Центра Китай - АСЕАН от 25 октября 2009 г., в Пекине был открыт Центр Китай - АСЕАН (ноябрь 2011 г.), который является единственной межправительственной структурой. Цель Центра - «укрепление взаимопонимания между народами Китая и АСЕАН», а приоритетными направлениями являются обмены в области традиционного искусства, ремесла, музыки, танца, театра, кино и языка ${ }^{22}$. В июне 2012 г. в Центре состоялась презентация, направленная на привлечение большего числа студентов из стран АСЕАН на обучение в Китай, во время которой сотрудники Китайского стипендиального совета представили программы стипендий правительства начальникам отделов образования при посольствах государств - членов $\mathrm{ACEAH}^{23}$.

По состоянию на конец 2012 г. в более чем десяти китайских вузах велось изучение языков народов стран Ассоциации. Пекинский университет, Пекинский университет иностранных языков, Гуйчжоуский университет и Юньнаньский университет открыли Центры исследования АСЕАН, что способствовало сотрудничеству с университетами Ассоциации ${ }^{24}$.

По оценке автора, в истории культурного сотрудничества Китая и Ассоциации следует выделить 2013-2021 гг. как «этап совершен-

${ }^{21} 2012$ Чжунго дунмэн хэцзо (Сотрудничество между Китаем и АСЕАН в 2012 г.) // МИД КН P. [Электронный pecypc]. 2012. URL: https://www.fmprc.gov.cn/web/gjhdq_676201/gjhdqzz_681 964/lhg_682518/zywj_682530/t990371.shtml(дата обращения: 05.09.2021).

22 Чжунго хэ дунмэн чэнюаньго чжэнфу гуаюй цзянли чжунго дунмэн чжунсин дэ лянцзе вэйванлу (Меморандум о взаимопонимания между правительство КНР и правительствами стран-участниц АСЕАН о создании центра Китай-АСЕАН) // Центр Китай-АСЕАН. [Электронный ресурс]. 2011. URL: http://www.asean-china-center.org/2011-05/17/c_13878731_2.htm (дата обращения: 05.09.2021).

${ }_{23}$ Чэн Дэхай. Чжунго дунмэн чжунсинь гунцзо наньбао 2012 (Ежегодник развития Центра КНР-АСЕАН 2012 г.). Пекин: Чжунго дунмэн чжунсинь, 2012. С. 23.

${ }^{24}$ Чжунго дунмэн хэцзо 1991-2011 (Сотрудничество между КНР и АСЕАН в 1991-2011 гг.) // МИД КНР. [Электронный ресурс]. 2011. URL: https://www.fmprc.gov.cn/web/wjdt_674879/sjx w_674887/t877316.shtml (дата обращения: 05.09.2021). 
ствования». В октябре 2013 г. председатель Китая Си Цзиньпин нанес визит в Индонезию, Таиланд и Малайзию. 3 октября 2013 г., выступая в парламенте Индонезии (первое выступление руководителя иностранного государства в индонезийском парламенте), он инициировал совместное построение «Морского Шелкового пути» и «Сообщества единой судьбы» с $\mathrm{ACEAH}^{25}$.

9 октября 2013 г. на 16-м заседании «АСЕАН+КНР» премьер Госсовета Китая Ли Кэцян заявил о наступлении «новой эры развития взаимоотношений КНР - АСЕАН» и предложил новый формат развития отношений на следующее десятилетие (2014-2024 гг.), при этом одним из семи приоритетных направлений объявлялось культурное сотрудничество. Для активизации взаимодействия в области культуры Ли Кэцян объявил 2014 год Годом культурных обменов КНР и $\mathrm{ACEAH}^{26}$. По мнению директора Центра КНР и АСЕАН Чэн Дэхай, сотрудничество между Китаем и АСЕАН вступило в новый этап сближения народов ${ }^{27}$.

На церемонии открытия Года культурных обменов КитайАСЕАН (7 апреля 2014 г.) вице-премьер Госсовета КНР Лю Яньдун отметила, что развитие дружественных отношений посредством культурного диалога имеет ключевое значение ${ }^{28}$. По данным Центра Китай - ACEAН, в рамках Года культурных обменов было реализовано более 150 мероприятий, включая конференции, выступления, выставки, обучение и обмен кадрами в области кино и телевидения. Центр Китай - АСЕАН, Министерство культуры и Китайская группа восточных исполнительских искусств совместно организовали 12 культурных мероприятий в странах АСЕАН. Среди них в Камбодже 2, во Вьетнаме - 2, в Индонезии - 4 и в Малайзии - 4. Данные культурные мероприятия привлекли в общей сложности 30 тыс. зрителей. По мнению генерального секретаря Центра Китай - АCЕАН Чэнь

\footnotetext{
${ }^{25}$ Си Цзиньпин цзай иньни гохуэй дэ яньцзян (Выступление Си Цзиньпина в Национальном Собрании Индонезии) // Правительство КНР. [Электронный ресурс]. 2013. URL: http://www.g ov.cn/ldhd/2013-10/03/content_2500118.htm (дата обращения: 05.09.2021).

26 Ли Кэцян цзунли цзай ди ши люй цы чжунго юй дунмэн лидаожэнь жуэйи шан дэ цзянхуа (Выступление премьера Госсовета Вэнь Цзябао на шестнадцатой встрече лидеров Китая и АСЕАН) // Министерство иностранных дел Китайской Народной Республики. [Электронный pecypc]. 2013. URL: https://www.fmprc.gov.cn/web/gjhdq_676201/gjhdqzz_681964/lhg_682518/ zyjh_682528/t1086491.shtml (дата обращения: 05.09.2021).

27 Чэн Дэхай. Чжунго дунмэн чжунсинь гунцзо наньбао 2013 (Ежегодник развития Центра КНР-АСЕАН 2013 г.). Пекин: Чжунго дунмэн чжунсинь, 2013. С. 3.

${ }^{28}$ Год культурных обменов Китай-АСЕАН открылся в Пекине // Портал Жэньминь. [Электронный ресурс]. 2014. URL: http://russian.people.com.cn/31513/95187/8591401.html (дата обращения: 05.09.2021).
} 
Дэхая, эти мероприятия способствовали улучшение взаимопонимания между народами и повысили авторитет Центра в Юго-Восточной Азии. В рамках Года культурных обменов Министерство культуры КНР направило художественные группы в Камбоджу, Вьетнам, Индонезию и Малайзию ${ }^{29}$.

В марте 2015 г. в Тяньцзиньском университете прошла церемония открытия Фестиваля искусств «Морской шелковый путь»; в мероприятии приняли участие семь университетов из стран $\mathrm{ACEAH}^{30}$. В апреле того же года при поддержке Центра Китай - ACEAН в Мьянме была проведена выставка по обмену произведениями буддийского искусства, а в Лаосе - лекция по магической акробатике ${ }^{31}$. В мае 2015 г. в рамках ЕХРО КНР - АСЕАН (г. Наньнин) состоялась культурная выставка на тему «Строительство Шелкового пути XXI века и содействие культурному сотрудничеству Китая и АСЕАН», в которой приняли участие 450 учреждений и компаний из Китая, Японии, Южной Кореи и стран АСЕАН ${ }^{32}$.

В рамках Международного кинофестиваля «Шелковый путь» (г. Сиань, сентябрь 2016 г.) была организована Неделя фильмов стран ACEAH; в мероприятии участвовала делегация в составе 40 человек, подписавшая соглашение о сотрудничестве в области кинематографии. Гу Сюлянь, президент Общества дружбы Китай - АCЕАН, отметил, что это мероприятие проводилось в Китае впервые, и выразил уверенность, что оно станет доброй традицией ${ }^{33}$.

В марте 2017 г. в Гуанси была создана Ассоциация университетов искусств Китая и АСЕАН. Декларацию о создании Ассоциации подписали 8 китайских университетов и университеты из 11 стран АСЕАН. Это событие означало появление новой платформы для культурного и образовательного сотрудничества между сторонами ${ }^{34}$.

В июне 2018 г. при поддержке Фонда памяти Сун Цинлина (заместитель председателя КНР в 1959-1975 гг.) состоялась детская

\footnotetext{
${ }^{29}$ Чэн Дэхай. Чжунго дунмэн чжунсинь гунцзо наньбао 2014 (Ежегодник развития Центра КНР-АСЕАН 2014 г.). Пекин: Чжунго дунмэн чжунсинь, 2014. С. 36.

${ }^{30}$ Чэн Дэхай. Чжунго дунмэн чжунсинь гунцзо наньбао 2015 (Ежегодник развития Центра КНР-АСЕАН 2015 г.). Пекин: Чжунго дунмэн чжунсинь, 2015. С. 37.

${ }^{31}$ Чэн Дэхай. Чжунго дунмэн чжунсинь гунцзо наньбао 2015 (Ежегодник развития Центра КНР-АСЕАН 2015 г.). Пекин: Чжунго дунмэн чжунсинь, 2015. С. 38

${ }^{32}$ Там же.

${ }^{33}$ Чэн Дэхай. Чжунго дунмэн чжунсинь гунцзо наньбао 2016 (Ежегодник развития Центра КНР-АСЕАН 2016 г.). Пекин: Чжунго дунмэн чжунсинь, 2016. С. 46.

34 Чэн Дэхай. Чжунго дунмэн чжунсинь гунцзо наньбао 2017 (Ежегодник развития Центра КНР-АСЕАН 2017 г.). Пекин: Чжунго дунмэн чжунсинь, 2017. С. 48.
} 
книжная ярмарка Китай - АCЕАН, которая, по оценке заместителя председателя Фонда Хан Юаньсяна, «помогла посеять семена дружбы в сердцах людей и заложить основы для строительства Сообщества единой судьбы КНР - АСЕАН» ${ }^{35}$.

В марте 2019 г. в Сиане (столице провинции Шанси, где находился Восточный конец Великого шелкового пути), состоялось торжественное мероприятие «Культурный город Восточной Азии» с участием более 200 представителей из стран «АСЕАН+3». На форуме обсуждались вопросы культурных обменов между городами и защиты культурного наследия. Церемония запуска Сети культурных городов «АСЕАН+3» началась с г. Янчжоу (провинция Цзянсу) в октябре 2019 г., когда заместитель министра культуры Китая подписал документ «Инициативы сети культурных городов АСЕАН+3» с представителями стран АСЕАН, а также Японии и Южной Кореи ${ }^{36}$.

В ноябре 2019 г. в провинции Хайнань прошла Неделя культуры студентов КНР - АСЕАН с участием 15 художественных вузов из стран Ассоциации, став новой платформой для культурных и художественных обменов ${ }^{37}$.

С 2012 г. Форум культурной индустрии был переименован в Культурный форум и включен в рамочную систему ЕХРО Китай АСЕАН. При этом тематика Форума расширилась от культурной индустрии до сотрудничества в области библиотечного дела (2012 г.), нематериального культурного наследия (2013 г.), художественного образования (2016 г.) и традиционного искусства $(2017 \text { г. })^{38}$.

Основной дискуссией Культурного форума в 2013 г. стала охрана нематериального культурного наследия. В декабре 2020 г. совместный объект Китая и Малайзии «Церемония вручения королевского корабля» был включен в Список нематериального культурного наследия ЮНЕСКО. Министр туризма, искусства и культуры Малайзии Нэнси Шукри заявила, что Малайзия выдвигает для ЮНЕСКО совместный проект впервые ${ }^{39}$.

\footnotetext{
35 Чэн Дэхай. Чжунго дунмэн чжунсинь гунцзо наньбао 2018 (Ежегодник развития Центра КНР-АСЕАН 2018 г.). Пекин: Чжунго дунмэн чжунсинь, 2018. С. 62.

${ }^{36}$ Чэн Дэхай. Чжунго дунмэн чжунсинь гунцзо наньбао 2019 (Ежегодник развития Центра КНР-АСЕАН 2019 г.). Пекин: Чжунго дунмэн чжунсинь, 2019. С. 74.

${ }^{37}$ Там же.

38 Чжунго дунмэнвэньхуа луньтань цзоугуо ши и нянь (11 лет культурному форуму КитайACEAH) // Новости Китая. [Электронный ресурc]. 2017. URL: http://www.gx.chinanews. com/dmwt/2017-09-01/detail-ifzanvsu6106735.shtml (дата обращения: 05.09.2021).

${ }^{39}$ Малай сия жэнши ббяоши ляньхэ шэньи чэнгун тисянь мачжун гуанси мице (Успешная совместная заявка на присоединение объекта в список нематериальных культурных наследий
} 
На 12-й сессии ЕХРО Китай - АСЕАН (сентябрь 2015 г.) вицепремьер Госсовета Чжан Гаоли подчеркнул готовность Китая реализовать рассчитанный на 2014-2018 гг. План действий Китай - ACEАН в области культурного сотрудничества и совместно создавать культурные центры в странах Ассоциации ${ }^{40}$. К 2020 г. было создано 37 китайских культурных центров по всему миру, из них 7 - в странах - членах ACEAН: Бангкок (Таиланд, ноябрь 2012 г.), Вьентьян (Лаос, ноябрь 2014 г.), Сингапур (ноябрь 2015 г.), Пномпень (Камбоджа, ноябрь 2016 г.), Ханой (Вьетнам, ноябрь 2017 г.), Янгон (Мьянма, ноябрь 2017 г.), Куала-Лумпур (Малайзия, январь 2020 г.) $[10$, c. 3]. По данным Министерства культуры Китая, к 2020 г. запланировано построить 50 культурных центров за рубежом [16, с. 9]. В работе этих структур министерство выделяет три направления: культурная деятельность, информационные и образовательные услуги.

В целях построения культурной державы и укрепления «мягкой силы культуры» КНР на международной арене, 26 января 2017 г. ЦК КПК и Госсовет выпустили «Мнения о реализации проекта по сохранению и развитию превосходной традиционной китайской культуры». В документе указывается, что необходимо использовать зарубежные китайские культурные центры, Институты Конфуция, выставки культурных реликвий, фестивали кино и другие платформы для содействия распространению китайской традиционной культуры в мире. В качестве приоритетов определены китайская опера, народная музыка, каллиграфия и традиционная китайская живопись, Ушу, китайская кухня и традиционная китайская медицина [15, с. 268].

Основной формой популяризации традиционной культуры в зарубежных культурных центрах является Неделя нематериальных культурных ценностей. Например, в июне и августе 2017 г. она была проведена в Лаосе, Сингапуре, Таиланде, Камбодже и сопровождалась показом национальных танцев, обычаев, достижений традиционной медицины и т.д ${ }^{41}$. В условиях пандемии (2020 г.) культурные

ЮНЕСКО отражала тесные взаимоотношения между Китаем и Малайзией) // Агентство Синьхуа. [Электронный ресурс]. 2020. URL: http://www.xinhuanet.com/2020-12/18/c_1126879 680.htm (дата обращения: 05.09.2021).

${ }^{40}$ Чжан Голи цзай ди ши эр це чжунго дунмэн болайнхуэй шан дэ чжицы (Выступление Чжан Гаоли на 12-й выставке Китай-АСЕАН) // Правительство КНР. [Электронный ресурс]. 2015. URL: http://www.gov.cn/guowuyuan/2015-09/18/content_2935007.htm (дата обращения: 05.09.2021).

${ }^{41}$ Хайвай чжунго вэньхуа чжунсинь чуньчэн юй чуансинь чжунго фэйи вэньхуа чжоу ячжоу (Неделя нематериальных культурных ценностей в рамках китайских культурных центров в А 
центры запустили онлайн-просмотр фильмов и онлайн-туристические мероприятия, публикуют информацию о своей деятельности в социальных сетях ${ }^{42}$.

По данным за 2020 г., внешнеторговый оборот Китая и АСЕАН составил 684,6 млрд долл. ${ }^{43}$ АСЕАН обогнала ЕС и стала крупнейшим торговым партнером Пекина, а Китай сохраняет свои позиции крупнейшего торгового партнера АСЕАН 12 лет подряд ${ }^{44}$. В этих условиях растет спрос на услуги по изучению китайского языка. По состоянию на 2019 г. в странах АСЕАН функционировало 37 институтов Конфуция и 34 классов Конфуция. Согласно Белой книге «Международное сотрудничество Китая в целях развития в новую эру», выпущенной Информационным бюро Госсовета КНР в январе 2021 г., в 2013-2018 гг. Китай направил примерно 20 тыс. волонтеров в более чем 80 стран $^{45}$. По оценке профессора Центра инноваций Морского Шелкового пути Тан Сяосуна, посредством Институтов Конфуция, дислоцируемых в АСЕАН, создаются значительно лучшие условия для желающих изучать китайский язык и культуру, что позволяет укреплять взаимопонимание и снижать негативное влияние теории «китайской угрозы», усиливать влияние КНР в АСЕАН $[11$, c. 43$]$.

В июле 2021 г. в выступлении на церемонии открытия симпозиума в честь 30-ой годовщины установления диалоговых отношений между Китаем и АСЕАН министр иностранных дел КНР Ван И отметил значительный рост студенческих обменов между Китаем и ACE-

зии) // Культура Китая. [Электронный ресурс]. 2017. URL: http://cn.chinaculture.org/portal/site/ wenhua/special_report/list.jsp?treeCode=200001005257001 (дата обращения: 05.09.2021).

${ }^{42}$ Хэ кэй чжунго вэньхуа чжунсинь туй цюй Юй ю чжунго (Открытие культурной мероприят ии путешествия по Китаю через виртуальную платформу культурного центра в Ханое) // Кит айский культурный цент за рубежом. [Электронный ресурс]. 2020. URL: http://cn.chinaculture. org/portal/pubinfo/2020/05/27/200001003002001/5c3e138a83c744998a40de471 ece2f22.html (дата обращения: 05.09.2021).

432020 нянь чжунго дунмэн цзинмао хэцзо цзянькуан (Обзор торгово-экономического сотрудничества Китая и АСЕАН в 2020 году) // Министерство торговли КНР. [Электронный pecypc]. 2021. URL: http://asean.mofcom.gov.cn/article/o/r/202101/20210103033653.shtml (дата обращения: 05.09.2021).

44 Дунмэн юэшэн чжунго цзуйда хуоу маои хуобан (АСЕАН стала крупнейшим торговым партнером Китая) // Правительство КНР. [Электронный ресурс]. 2021. URL: http://www.gov. cn/xinwen/2021-02/02/content_5584276.htm (дата обращения: 05.09.2021).

${ }^{45}$ Синьшидай дэ чжунго гоцзи фачжань хэцзуо вэйпи шу (Белая книга о международном сотрудничестве Китая в целях развития в новую эру) // Агентство Синьхуа. [Электронный реcypc]. 2021. URL: http://www.xinhuanet.com/2021-01/10/c_1126965418.htm (дата обращения: 05.09.2021). 
АН, в которых участвуют более 200 тыс. человек ${ }^{46}$, при этом в Китае учатся почти 100 тыс. студентов, из них 15 тыс. получили стипендии правительства Китая ${ }^{47}$. Посол Китая в АСЕАН Сюй Бу рассматривает студентов как носителей и распространителей культур своих народов, высоко оценивает их вклад в строительство Сообщества единой судьбы Китая и АСЕАН [12, с. 11].

Выводы. Таким образом, в развитии культурной дипломатии КНР в отношении АСЕАН можно выделить два этапа: 2003-2012 гг. этап становления, 2013-2021 гг. - этап активизации сотрудничества.

Среди факторов, влияющих на культурное взаимодействие, выделяются: 1) на этапе становления - взаимное доверие в вопросах политики и безопасности, заинтересованность в создании зоны свободной торговли, 2) на этапе совершенствования - продвижение строительства Сообщества единой судьбы и социально-культурного Сообщества Китая и АСЕАН.

На основе концепции стратегического партнерства с АCEAH перед китайской культурной дипломатией были поставлены следующие задачи: 1) создание мирной и стабильной региональной среды для модернизации страны 2) снижение негативного отношения к усилению влияния Китая и инициативе «Морской шелковый путь».

В соответствии с вышеупомянутыми задачами китайская культурная дипломатия в отношении АСЕАН определяет три уровня субъектов реализации: официальные учреждения, предприниматели и студенты.

Основными площадками реализации культурной дипломатии, осуществляемой официальными учреждениями, являются саммиты АCЕАН+3 и АСЕАН+Китай, заседания министров культуры ACEАН+3 и АСЕАН+Китай, Центр Китай - АСЕАН. Платформами для предпринимателей, занимающихся культурной индустрией, стали ЕХРО Китай - АСЕАН, Форум культурной индустрии, Общество дружбы Китай - АСЕАН. Студенческие обмены реализуют Комитет

\footnotetext{
${ }^{46}$ Ван И цзай чжунго дунмэн цзянли дуйхуа гуанси саньши чжоунань цзинань яньтаохуэй каймуши шандэ чжисы (Выступление министра иностранных дел Ван И на церемонии открытия симпозиума в честь 30-ой годовщины установлению диалоговых отношений между Китаем и АСЕАН) // МИД КНР. [Электронный ресурс]. 2021. URL: https://www.fmprc. gov.cn/web/ziliao_674904/zt_674979/dnzt_674981/qtzt/jnzghflhghfxw_1/t1895884.shtml (дата обращения : 05.09.2021).

47 Ли Сяохун, Пэн Вэньцю. Синь чжунго чэнли и лай чжунго дунмэн гаодэн цзяоюй хэцзо дэ хуэйгу юй чжаньван (Ретроспектива и перспективы сотрудничества в области высшего образования между КНР и АСЕАН с момента основания Нового Китай) // Исследование истории образования. 2021. № 9. С. 121.
} 
КНР по управлению стипендиальным фондом обучения за границей и сеть институтов Конфуция. Посредством этих структур Пекин укрепляет культурные связи с АСЕАН и формирует позитивный образ Китая в регионе.

\section{Библиографические ссылки}

1. Ли Фуцяян Чжунго юй дунмэн цзяолю хэцзоши яньцзю вэньхуа цзюань (Исследование истории обменов и сотрудничества в области культуры между КНР и АСЕАН). Пекин : Миньцзу, 2006. 280 с.

2. Цзян Юлиан Инсян чжунго дунмэн вэнхуа хэ цзо дэ иньсу цзи дуйцэ фэньси (Анализ факторов, влияюших на культурное сотрудничество между Китаем и АСЕАН) // Вестник Университета Гуанси. 2006. № 5. С. 21-26.

3. Хуан Цзюнь Жуаньшили юньюн туйцзи чжунго юй дунмэн хэцзо дэгуаньцзя (Продвижение сотрудничества между Китаем и АСЕАН посредством применения мягкой силы) // Современные международные отношения. 2009. № 8. С. 8-12.

4. Чжан Чэнся Гоуцзянь чжунго дунмэн жэньвэнь цзяолю синьгэцзю (Построение новой модели кульутрно-гуманитарного сотрудничества КНР и АСЕАН) // Юго-восточная Азия. 2012. № 11. С. 21-26.

5. Ли Хун, Чжу Минминь Вэньхуа вайцзяо юй цзинцзи вайцзяо сетяо фачжань и чжунго дунмэн хэцзо вэйли (Исследование согласованного развития культурной дипломатии и экономической дипломатии: на примере КНР и АСЕАН) // Вестник Университета Гуанси. 2012. № 5. С. 12-18.

6. Хуан Яодун Чжунго дунмэн вэньхуа цзяолю юй хэ цзо кэ синсин яньцзю (Исследование обоснования культурного сотрудничества КНР и АСЕАН) // Академический форум. 2014. № 11. С. 137-142.

7. Ян Хуа Чжунго дунмэн вэньхуа цзяолю цзуаньши шинянь дэ гоцзянь яньцзю (Исследование культурных обменов между Китаем и АСЕАН за первое десятилетие XXI века) // Гуанси шэхуэй кэсюй вэнсянь. 2014. № 5. С. 43-47.

8. Чжао Цзянь, Чжао И. Вэньхуа вайцзяо чжунго цзюань (Культурная дипломатия Китая). Пекин: Шицзе чжиши, 2014. 385 с.

9. Чжан Юйдун, Чжуан Гочи Чжунго дунмэн юй ччжунтай гуаньси яньцзю (КНР-АСЕАН и отношения Китая и Таиланда) - Пекин: Шэхуэй кэсюй вэньсянь, 2015. 339 с.

10. Чж⿻у Шисинь Дунмэн дэ вэньхуа чжаньлюй юй чжунго дэ сюаньцзэ (Культурная стратегия АСЕАН и варианты политики Китая) // Обучение и исследование. 2016. № 11. С. 80-87.

11. Тан Сяосун, Цзин Лина Чжунго дуй дунмэн дэ гуггун вэйцзяо сянь чжуан дуни юй фан сян (Публичная дипломатия Китая в отношении АСЕАН: состояние, мотивы и основные направления) // Исследование Юго-Восточной Азии. 2017. № 4. С. 38-51.

12. Чжан Цзи, Син Лицзюй Жэньвэнь хуачэн чжунго юй чжоубянь гоцзя дэ жэньвэнь цзяолю (Культурно-гуманитарные обмены между Китаем и соседними странами). Пекин: Шице чжиши, 2018. $226 \mathrm{c.}$

13. Ли Чинлинь Чжунго дунмэн инши хэцзую яньцзю (Исследование взаимодействия в области теле- и кинематографии) // Журнал исследования прессы. 2018. № 20. С. 19-21.

14. Лян Жучцян, Ян Хайгуан Цзэнцян вого цзай дунмэн гоцзя инсянли дэ яньцзю (Исследование по усилению влияния китайской культуры в странах АСЕАН) // Журнал культуры. 2019. № 10. C. $81-84$.

15. Чжан Сипин Чжунго вэньхуа цзоу чуцюй яньцзю баогао цзунлу 2018 (Доклад о развитии китайской культурной стратегии “Идти вовне” 2018 г.). Пекин: Шэхуэй кэсюй вэнсянь, 2019. $283 \mathrm{c}$.

16. Юй Хунзюнь Ко да жэньвэнь цзяолю юй хэцзо цзяхуа чжунго дунмэн минюнь гунтунти иши (Расширение культурно-гуманитарного сотрудничества с целью формирования общего 
сознания создания Сообщества единой судьбы КНР и АСЕАН) // Публичная дипломатия. 2020. № 4. С. 1-26.

17. Син Лиизюй Чжунвэй жэньвэнь цзяолю гайлун (Культурно-гуманитарные обмены между Китаем и иностранными странами) - Пекин: Шицзе чжиши, 2021. 334 с.

18. Полончук Р. А. Политика КНР в Юго-Восточной Азии // Проблемы Дальнего Востока. 2020. № 3. С. 4-24.

19. Файншмидт Р. И. Китайский вектор современной политики АСЕАН // Юго-Восточная Азия: актуальные проблемы развития. 2018. № 4. С. 29-38.

20. Чжай Кунь 1991-2020: подъем Китая и развитие отношений между Китаем и АСЕАН: исторический обзор и стратегия на будущее / Кунь, Чжай // Проблемы Дальнего Востока. 2005. № 5. C. 32-43.

Дата поступления статьи: 14.09 .2021$.

Автор: Ши Даньдань - аспирант кафедры международных отношений Белорусского государственного университета (Минск); e-mail: dandanshi@yandex.by.

\title{
CULTURAL DIPLOMACY OF THE PRC TOWARDS ASEAN (2003-2021)
}

\author{
SHI DANDAN \\ Belarusian State University, Minsk, Republic of Belarus
}

\begin{abstract}
The article examines the main directions of China's cultural diplomacy towards the Association of Southeast Asian Nations in 2003-2021. ASEAN is not only a political and economic but also a cultural intergovernmental organization of 10 states, three of which are China's neighbours (Laos, Myanmar and Vietnam). A comprehensive analysis of the problem identifies three main areas of China's cultural diplomacy towards ASEAN: promotion of Chinese culture; popularization of Chinese language; and enhancement of educational exchanges. The contractual legal framework of cultural interaction is characterized, and the main mechanisms and tools of its implementation are identified.

It is the first comprehensive study of Chinese cultural diplomacy towards ASEAN in Belarusian historiography. The author has proved that dissemination of Chinese culture within ASEAN: 1) is mainly carried out through the establishment of Chinese cultural center and regular cultural events, including cultural forums, art and film festivals; 2) the main tool for promoting Chinese language in the ASEAN member countries is Confucius classes and institutions; 3) active development of educational contacts with the members of the Association attracts more students from this region to China; by 2021 their number reached almost 100 thousand.

The results of this work can be used for comprehensive studies of PRC foreign policy and diplomacy.

Keywords: PRC; ASEAN; foreign cultural policy; cultural diplomacy; multilateral cultural ties; cultural strategy; strategic partnership; Community of shared future for mankind.
\end{abstract}


For citation: Shi Dandan (2021). Kul'turnaya diplomatiya KNR v otnoshenii ASEAN (2003-2021 gg.) [Cultural policy of the PRC towards ASEAN (2003-2021)]. In: Actual problems of international relations and global development: collection of scientific papers. Minsk, Vol. 9, p. 162-180. https://doi.org/10.33581/2311-94702021-9-162-180

\section{References}

1. Li Fuqiang. (2006). Zhong guo yu dong meng jiao liu he zuo shi yan jiu wen hua juan [Research on the history of exchanges and cooperation between China and ASEAN in the cultural field]. Beijing: Min zu chu ban she. p. 280. (In Chin.).

2. Jiang Yulian. (2006). Xing xiang zhong guo dong meng wen hua jiao liu yu he zuo de yin su ji dui ce fen xi [Analysis of factors influencing cultural cooperation between China and ASEAN]. In: Guang xi da xue xue bao. No. 5, 21-26 p. (In Chin.).

3. Huang Jun. (2009). Ruan shi li yun yong tui jin zhong guo yu dong meng he zuo de guan jian [Promoting cooperation between China and ASEAN through the use of soft power]. In: Xian dai guo ji guan xi. No. 8, 8-12 p. (In Chin.).

4. Zhang Chengxia. (2012). Gou jian zhong guo dong meng ren wen jiao liu xin ge ju [Building a new model of cultural and humanitarian cooperation between the PRC and ASEAN]. In: Dong nan ya zong heng. No. 11, 21-26 p. (In Chin.).

5. Li Hong, Zhu Mingmin. (2012). Wen hua wai jiao yu jing ji wai jiao xie tiao fa zhan chu tan yi zhong guo dong meng he zuo wei li [Research on the interrelationship between cultural diplomacy and economic diplomacy: taking the cooperation between China and ASEAN as an example]. In: Guang xi da xue xue bao. No. 5, 12-18 p. (In Chin.).

6. Huang Yaodong.(2014) Zhong guo dong meng wen hua jiao liu yu he zuo ke xing xing yan jiu [Research on the feasibility of cultural exchanges and cooperation between China and ASEAN]. In: Xue shu lun tan. No. 11, 137-142 p. (In Chin.).

7. Yang Hua. (2014) Zhong guo dong meng wen hua jiao liu zuan shi shi nian de gou jian yan jiu [A study of cultural exchanges between China and ASEAN in the first decade of the 21st century]. In: Guang xi she hui ke xue. No. 5, 43-47 p. (In Chin.).

8. Zhao Yi, Zhao Jian. (2014). Wen hua wai jiao zhong guo juan [China's cultural diplomacy]. Beijing: Shi jie zhi shi. p. 385. (In Chin.).

9. Zhang Yudong, Zhuang Guotu. (2015). Zhong guo dong meng yu zhong tai guan xi yan jiu [Research on China-ASEAN and China-Thailand relations]. Beijing: she hui ke xue wen xian. p. 339. (In Chin.).

10. Zhou Shixin. (2016). Dong meng de wen hua zhan lv yu zhong guo de zheng ce xuan ze [Cultural strategy of the ASEAN and policy options in China]. In: Jiao xиe yu yan jiu. No. 11, 80-86 p. (In Chin.).

11. Tang Xiaosong, Jing Lina. (2017). Zhong guo dui dong meng de gong gong waij jiao xian zhuang dong yin yu fang xiang [China's public diplomacy towards ASEAN: status quo, motivation and main directions]. In: Dong nan ya yan jiu. No. 4, 38-51 p. (In Chin.).

12. Zhang Ji, Xing Liju. (2018). Ren wen hua cheng zhong guo yu zhou bian guo jia ren wen jiao liu [Cultural and humanitarian exchanges between China and neighboring countries]. Beijing: Shi jie zhi shi. p. 226. (In Chin.).

13. Li Qinglin. (2018). Zhong guo dong meng ying shi he zuo yan jiu [Study of interaction in the field of television program and cinematography]. In: Xin wen yan jiu dao kan. No. 20, 19-21 p. (In Chin.).

14.Liang Ruqian, Yang Haiguang. (2019). Zeng qiang wo guo wen hua zai dong meng guo jia ying xiang li de yan jiu [Research on enhancing the influence of Chinese culture in ASEAN countries]. In: Wen hua xue kan. No. 10, 81-84 p. (In Chin.). 
15. Zhang Xiping. (2019) Zhong guo wen hua zou chu qu yan jiu bao gao zong lun [Research report on Chinese cultural strategy "go global"]. Beijing: She hui ke xue wen xian. p. 283. (In Chin.).

16. Yu Hongjun. (2020). Kuo da ren wen jiao liu yu he zuo qiang hua zhong guo dong meng mingy un gong tong ti yi shi [Strengthen the sense of community of shared destiny between China and ASEAN by expanding cultural exchanges and cooperation]. In: Gong gong wai jiao ji kan. No. 4, 1-6 p. (In Chin.).

17. Xing Liju. (2021). Zhong wai ren wen jiao liu gai lun [Cultural and humanitarian exchanges between China and foreign countries]. Beijing: She jie zhi shi. p. 334. (In Chin.).

18. Polonchuk R. A. (2020). Politika KNR v Jugo-vostochnoj Azii [PRC's policy in Southeast Asia]. In: Problemy Dal'nego Vostoka, No. 3. p. 4-24. (In Russ.).

19. Feinschmidt, R. I. (2018). Kitajskij vektor sovremennoj politiki ASEAN [Chinese vector of modern ASEAN's politics]. In: Jugo-Vostochnaja Azija: aktual'nye problemy razvitija, No. 4. p. 29-38. (In Russ.).

20. Zhai Kun. (2005). 1991-2020: podem Kitaja i razvitie otnoshenij mezhdu Kitaem i ASEAN: storicheskij obzor i strategija na budushhee [1991-2020: the rise of China and the development of relations between China and ASEAN: a historical overview and strategy for the future]. In: Problemy Dal'nego Vostoka, No. 5. p. 32-43. (In Russ.).

Received: 14.09 .2021 .

About author: Shi Dandan - post-graduate student of the Faculty of International Relations, Belarusian State University, Minsk, Republic of Belarus, e-mail: dandanshi@yandex.by. 